\title{
DETECTING RED FLAGS OF CORPORATE FINANCIAL STATEMENT FRAUDS USING BENEISH M SCORE MODEL IN SRI LANKA
}

\author{
G.M. Mudith Sujeewa, M.D. Pubudu Kawshalya \\ University of Kelaniya, Sri Lanka
}

\begin{abstract}
Financial statement fraud is one of the major concerns in the modern business world. Detecting financial statement fraud is very challenging task and requires thorough knowledge about the nature of fraud, how it can be committed and concealed. The purpose of the study is to identify the red flags of financial statement frauds applying Benish M Score model. It is found that, in each year (2013-2019) considered for the study, there are companies with a Beneish M Score of greater than -2.22, which can be gauged for possible manipulations on those financial statements. Paired sample t-test analysis is showen that, DSRI (Days' Sales in Receivables Index), GMI (Gross Margin Index), SGI (Sales Growth Index) LVGI (Leverage Index), TATA (Total Accruals to Total Assets) out of eight ratios occupied in the Beniesh model are significantly different between manipulated and non-manipulated firms. Therefore, it is recommended that Benish $M$ Score model can be used as a risk assessment tool to recognize the red flags of possible fiancial statemet frauds in business entities in Sri Lanka. This paper aims at broadening knowledge of External Auditors, Forensic Accountants, Accountants, Senior Managers, Regulators and other stakeholders in detecting red flags of financial statement frauds in Sri Lanka.
\end{abstract}

Keywords: Benish M Score Model, Financial Statement Fraud, Days' Sales in Receivables Index, Gross Margin Index, Sales Growth Index, Leverage Index, Total Accruals to Total Assets

\section{Introduction}

Corporate frauds have existed from time ageold and grown over the centuries and become more complex and difficult to investigate resulting in dire consequences for businesses and the economy. Detecting fraud is not an easy task and requires a thorough knowledge of the nature of the fraud, why it was committed and concealed (Association of Certified Fraud Examiners, 2016). The "fraud triangle" developed by Cressey (1953) is a model for explaining the factors that cause someone to commit occupational fraud. It consists of three components which, together, lead to fraud: perceived unshareable financial need, perceived opportunity and rationalization (Cressey,1973). This fraud theory explains why trust violators commit fraud and is widely used by regulators, professionals and academics.
Many companies expect more returns from their employees in order to maximize their wealth. They contribute to the employees' ability to rationalize their behaviour even if it is unethical, illegal or fraudulent leading to fraud in organizations (Kassem \& Higson, 2012).

The survey by Association of Certified Fraud Examiners (2020) estimated that the typical organization loses $5 \%$ of revenue each year as a result of fraud. The total loss caused by the cases in the study exceeded USD 7 billion. The median loss for all cases in the study was USD 130,000 , with $22 \%$ of cases causing losses of USD 1 million or more. Asset misappropriation was by far the most common form of occupational fraud, occurring in more than $89 \%$ of cases, but causing the smallest median loss of USD 114,000. Financial statement 
fraud was at the other end of the spectrum, occurring in less than $10 \%$ of cases but causing a median loss of USD 800,000. Corruption cases fell in the middle, with $38 \%$ of cases and a median loss of USD 250,000 (Report to Nations, 2018). Furthermore, most discoveries occur more by whistle-blowers' tips than predesigned internal control systems providing evidence that $39.1 \%$ of fraudulent activities are discovered by employee tips (Association of Certified Fraud Examiners, 2018).

The nature of fraud is that much of its cost is hidden. Because concealment is an intrinsic component of most fraud schemes, some frauds are never uncovered; further, of the cases that are detected, many are never measured or reported. In addition, most frauds carry substantial indirect costs, including lost productivity, reputational damage and related business losses, as well as costs associated with investigation and remediation of the issues that allowed them to occur. The result is the equivalent of a financial iceberg; some of the direct losses are plainly visible, but there is a huge mass of hidden harm that we cannot see (Association of Certified Fraud Examiners, 2016).

Financial statement fraud continues to be a significant problem for businesses of all sizes. The generally accepted definition of financial statement fraud is "the deliberate misrepresentation of the financial condition of an enterprise accomplished through the intentional misstatement or omission of amounts or disclosures in the financial statements in order to deceive financial statement users" (Fraud Examiners Manual, 2016).

Financial statement fraud is the costliest type of fraud, generating median losses valued at USD 954,000 (Association of Certified Fraud Examiners, 2020). It can negatively influence the capital markets because of losing investor confidence and irrevocable damage to the company's reputation. Other major implications include significant losses of shareholder value due to abnormal stock price decline, delisting by the stock exchange, and
International Journal of Accounting \& Business Finance Vol.6.No.2 December 2020 Issue. pp. 71 - 81

material assets sales upon fraud discovery, etc. Financial statements frauds and manipulations have become a common problem in Sri Lanka too with consequences for business as well as the economy of the country as shown by a few recent corporate failures. In 2014 the High Court ordered the winding up of Touchwood Investments PLC following the crisis in the company and its inability to service the dues owed to investors. One of the main reasons leading to this situation at Touchwood Investments PLC was the manupulation of financial statements in valuing its plantations in accordance with the International Accounting Standard (IAS) 41: Agriculture. The company auditors, KPMG, Ford Rhodes, Thornton and Co., qualified the audit opinion on the ground that the discount rate used (12\%) was too low and did not reflect the long term risk free rate and the premium for other risk factors thus resulting in an overstatement of biological assets.

The collapse of the Golden Key Credit Card Company also signalled a systemic collapse of some large finance companies as well as banks and could be trigger the global financial crisis to spill over to Sri Lanka in 2008 due to the frauds and contraventions of the provisions of the Finance Act No.78 of 1988 . These financial scandals emphasize the need for tools to detect possible financial statement frauds in the companies.

Furthermore, KPMG Fraud Survey (2012) revealed that in Sri Lanka $83 \%$ of respondents accepted that incidents of fraud had increased while $62 \%$ maintained that fraud within their respective industries had increased in the same period. On the other hand, only 51\% accepted that fraud had increased in their own organizations. In turn, $70 \%$ of respondents agreed that there was fraud within their organizations, $64 \%$ of which were in the private sector and $89 \%$ in the government sector.

In addition, the EY Fraud Survey (2015) found that $91 \%$ of employees admitted that bribery and corruption were widely prevalent in Sri Lanka and 62\% attributed the increase in corruption to tough economic times and increased competition. Further, it exposed that offering entertainment (36\%) was justified in aiding business, $44 \%$ thought it was acceptable to amend financial reports to provide a more 
positive outlook of results and $46 \%$ said there had been no change in their companies' efforts to combat fraud, bribery and corruption over the last two years.

Therefore, it is important to investigate empirically the applicability of eight-variable Beneish M-model to ascertain the occurrence of financial statement fraud or the tendency to engage in earnings manipulation in public limited companies registered. Accordingly, the the objectives of the study are, first to test the validity of the eight-variables Beneish M-model, and second, to detect listed companies that manipulated the financial statements as per the eight-variables Beneish M-model, and third to identify listed companies that have not manipulated financial statements as per the eight-variables Beneish M-model, and finally to determine most significant variables in the Beneish M-model for detecting financial statement fraud in listed companies in Sri Lanka

\section{Literature Review}

The literature review summarizes the key findings of relevant research and systematically examines the fraud triangle theory, the fraud diamond theory and the Benish M Score Model and its usefulness for identifying red flags and detecting financial statement frauds.
International Journal of Accounting \& Business Finance Vol.6.No.2 December 2020 Issue. pp. 71 - 81

\subsection{Fraud Triangle}

Cressey (1953), working on his $\mathrm{PhD}$ in criminology, focused on embezzlers and interviewed about 200 people who had interacted for embezzling funds. He formulated his hypothesis as follows: "Trusted persons become trust violators when they conceive of themselves as having a financial problem which is non-sharable, are aware that this problem can be secretly resolved by violation of their position of financial trust and are able to apply it to their own conduct to adjust their conception of themselves as trusted persons to their conception of themselves as users of the entrusted finds or property" (Cressey, 1973).

Upon completion of his interviews, he developed what still remains the classic model for the occupational offender. Over the years, his hypothesis has become better known as the "Fraud Triangle". One leg of the triangle represents Pressure, the second leg Opportunity and the final leg stands Rationalization. The Fraud Triangle views them as key conditions that tend to be present when fraud occurs. Within each of these broad risk categories, many different and specific potential red flags may be visible within a company.

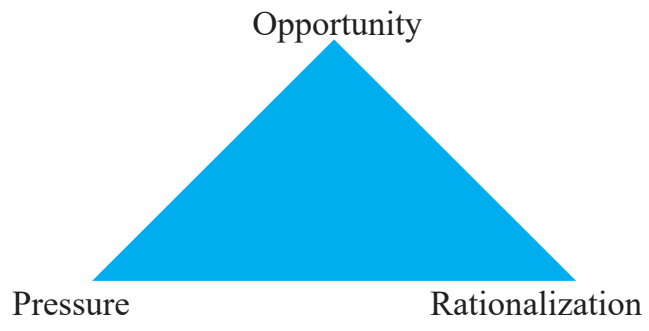

Figure 1: Fraud triangle

\subsubsection{Pressure}

Pressure, as explained by Cressey (1953), is the incentive that could motivate an individual to be involved in fraud. The pressure could result from personal problems such as financial pressures or addiction pressures, or from the work environment. Management or other employees may find themselves offered incentives or placed under pressure to commit fraud. For example, remuneration or advancement is significantly affected by individual, divisional, or company performance; and individuals may have an incentive to manipulate results or to put pressure on others to do so. Pressure may also come from the unrealistic expectations of investors, banks, or other sources of finance (Gupta, 2015). 


\subsubsection{Opportunity}

Pressure creates the motive for the crime to be committed, but the employee must also perceive that he/she has an opportunity to commit the crime without being caught. This perceived opportunity constitutes the second element. In Cressey's view, there are two components of the perceived opportunity to commit a trust violation: general information and technical skill. General information is simply the knowledge that the employee's position of trust could be violated. Technical skill refers to the abilities needed to commit the violation. These are usually the same abilities that the employees need to have in order to obtain and keep his position in the first place.

\subsubsection{Rationalization}

The third and final factor in the fraud triangle is rationalization. Cressey pointed out that rationalization is not an ex post facto means of justifying a theft that has already occurred. Significantly, rationalization is a necessary
International Journal of Accounting \& Business Finance Vol.6.No.2 December 2020 Issue. pp. 71 - 81

component of the crime before it takes place; in fact, it is part of the motivation for the crime. Because the embezzler does not view himself as a criminal, he must justify his misdeeds before he ever commits them. Rationalization is necessary so that the perpetrator can make his/her illegal behaviour intelligible to himself/ herself and to maintain his/her concept of himself/herself as a trusted person.

\subsection{Fraud Diamond Theory}

Wolfe and Hermonson (2004) argued in their research that perceived pressure or incentive might exist along with an opportunity and a rationalization to commit fraud, and fraud is unlikely to take place unless the fourth element is present: capability (capacity). In other words, potential perpetrators must have the skills and ability to commit a fraud. Hence, Wolfe and Hermonson (2004) added another variable, namely, capability to the conventional fraud triangle developed by Cressey in 1973. Figure 2 below presents the complete set of elements of the fraud diamond theory.

Opportunity

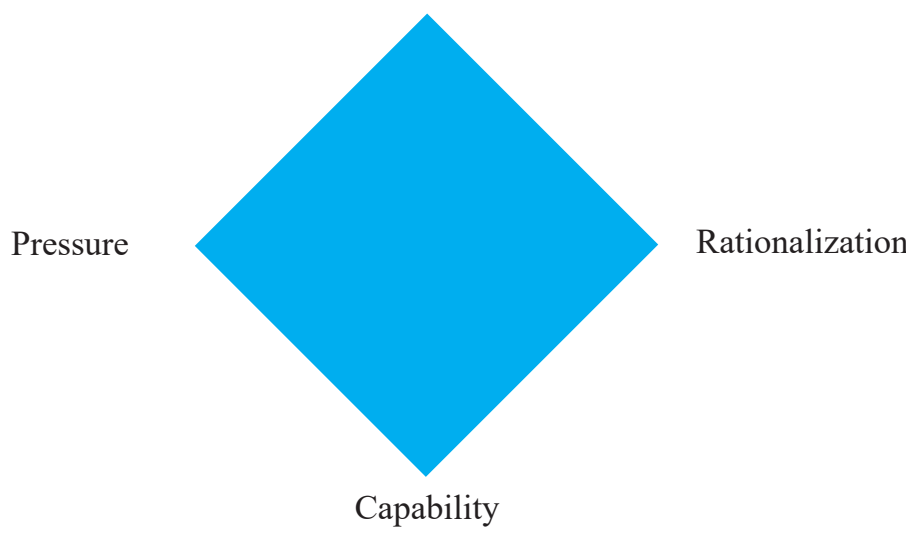

Figure 2: Fraud diamond 
The authors believe that the fraud triangle could be expanded to improve both fraud prevention and detection by considering a fourth element. In addition to addressing pressure, opportunity and rationalization, the researchers four sided "fraud diamond" also considers an individual's capability: personal traits and abilities as playing a major role in whether the fraud may occur even with the presence of the other three elements.

\subsubsection{Capability}

A person's position or function within a company may give him or her the ability to create or exploit an opportunity for fraud not available to others. According to Wolfe and Hermonson (2004), the fraudster also has the necessary traits and abilities to be the right person to pull it off and has recognised the fraud opportunity and can turn it into reality. Wolfe and Hermonson (2004) identified important observable traits related to the individuals' capacity to commit fraud. Those threats include: (a) authoritative position or function within the organization, (b) intelligence to exploit the accounting and internal control system, (c) ego and confidence, and (d) ability to effectively deal with stress.

\subsection{Beneish M Score Model}

Beneish (1999) developed a model to capture either the financial statement distortions that can result from manipulation or the preconditions that might prompt companies to engage in such activity. The results suggest a systematic relationship between the probability of manipulation and some financial statement variables. This evidence confirms the usefulness of accounting data for detecting manipulation and assessing the reliability of reported earnings. The model identifies approximately half the companies involved in earnings manipulation prior to public discovery.

Tarjo and Herawati (2015) analysed the ability of the M-score Beneish model to detect
International Journal of Accounting \& Business Finance Vol.6.No.2 December 2020 Issue. pp. 71 - 81

financial statement fraud. The results showed that overall model was able to detect financial statement fraud. Descriptive statistics and logistic regression analysis were employed to analyse the data. The gross margin index, depreciation index, index of sales and general administrative burden and total accruals were all significant in detecting financial statement fraud whereas sales index, asset quality index, and leverage index were found not statistically significant in detecting financial fraud. On the other hand, Repousis (2016) investigated empirically the eight-variables Beneish M-model to ascertain occurrence of financial statement fraud or tendency to engage in earning manipulation. The results showed that 8,486 companies or 33 per cent of the whole sample had a greater than -2.2 score, which signals that companies are likely to be manipulators. Also, for manipulators, results using F-distribution showed that days sales in receivable index (DSRI), asset quality index (AQI), depreciation index, selling, general and administrative expenses index (SGAI), total accruals to total assets index and leverage index (LVGI) were significant at 99 per cent confidence level in the Beneish M-score.

Kamal and Salleh (2016) measured the reliability of the Beneish M-Score model in detecting financial statement fraud in Malaysian public listed companies. They found it reliable in detecting earnings manipulation and financial statement fraud by $82 \%$ in 14 out of 17 listed companies charged for fraudulent financial reporting and irregularities in firms' financial reports.

MacCarthy (2017) examined whether the Altman Z-score and Beneish M-model could detect financial statement fraud and corporate failure of Enron Corporation. Five-year financial information was collected from the US SEC Edgar database covering the period 1996 to 2000. The Beneish M model revealed that the financial statements for the five years studied were manipulated by management. On the basis of this analysis, the researcher argued that stakeholders would be better protected when the two models are used simultaneously than when only the Altman Z-score is used and recommended that the Altman Z-score and Beneish M-Model should be used together as an integral part of every audit. Further, 
Talab, Flayyih, and Ali (2017) also examined the role of the Beneish M-score model in detecting earnings management practices using the data collected for listed banks on the Iraqi Stock Exchange in 2014 and 2015. The study concluded that the M-score model was useful for detecting earning manipulations and malpractices in the companies. Further, it can be applied to improve the quality of financial reporting for the protection of potential investors. Dalnial, Kamaluddin, Sanusi, and Khairuddin (2014)available between the year of 2000 and 2011. The study found that there are significant mean differences between the fraud and non-fraud firms in ratios such as total debt to total equity, account receivables to sales.

Anh and Linh (2016) examined earnings management detection among Vietnamese companies listed on the Hochiminh Stock Exchange (HOSE) using the Beneish M-score model in a sample of 229 non-financial Vietnamese listed companies during 20132014. The results showed that $48.4 \%$ nonfinancial Vietnamese listed companies were involved in earnings management and the sample observations fitted the Beneish M-score model. The M-score model was found to be useful for detecting earnings manipulation could be applied for better financial reporting quality and better protection for investors.

Razali and Arshad (2014) reported that the effectiveness of the corporate governance structure reduced the likelihood of fraudulent financial reporting and enhanced the credibility of financial reporting. The authors used an integrated Beneish M-score model and Altman's Z-score model to detect fraudulent financial reporting.

Accordingly, with the aim of understanding the fundamental motives of financial statement fraud, this exploratory study reveals the determinants of financial statement fraud and discusses the important aspects of detecting financial statement fraud in Sri Lankan organizations.

\section{Methodology}

This chapter explains the research strategy adopted, sampling process, data collection techniques and regression models of the study.

\subsection{Research approach}

There are two methodological approaches namely, quantitative and qualitative where the researcher selects based on ontological and epistemological assumptions. This study is addressing the nature of the problem using data followed by a theory, which involves testing of theories, symbolizes social reality as an external, objective reality. Thus, this study is quantitative as it is usually associated with positivism philosophical stance.

\subsection{Beneish M-Score}

Beneish (1999) developed a model to distinguish between earnings manipulators who violate accounting rules and nonmanipulators by utilizing financial statement variables. Prior to its development, he created a profile of earnings manipulating firms as identified by the US SEC's accounting enforcement measures. The model named Beneish M-score, consisted of eight ratios to capture either financial statement distortions resulting from earnings manipulation or to identify the inclination to engage in earnings manipulation as shown below:

$M$-Score $=-4.84+0.92 D S R I+0.528 G M I$ $+0.404 A Q I+0.892 S G I+0.115 D E P I-$ $0.172 S G A I+4.679 T A T A-0.327 L V G I$

The details of the eight independent variables in the form of indices based on Beneish (1999) are given below:

\section{DSRI: Days' Sales in Receivables Index}

This measures the ratio of the days' sales in receivables versus the prior year as an indicator of revenue inflation.

\section{GMI: Gross Margin Index}

This measured the ratio of gross margin versus prior year. A firm with poorer prospects is more likely to manipulate earnings.

\section{AOI: Asset Quality Index}

Asset quality is measured as the ratio of noncurrent assets other than property, plant and equipment to total assets versus the prior year. It intends to measure the company's risk propensity to capitalize cost.

\section{SGI: Sales Growth Index}

This measures the ratio of sales versus the prior 
year. While sales growth is not itself a measure of manipulation, the evidence suggests that growth companies are likely to find themselves under pressure to manipulate in order to keep up appearances.

\section{DEPI: Depreciation Index}

This is a measure of the ratio of the rate of depreciation versus the prior year. A slower rate of depreciation may mean that the firm is revising useful asset life assumptions upwards or adopting a new method that is income friendly.

\section{SGAI: Sales, General and Administrative Expenses Index}

This measures the ratio of SGA expenses to the prior year and is used on the assumption that analysts would interpret a disproportionate increase in sales as a negative signal about a firms' prospects.

\section{LVGI: Leverage Index}

This measures the ratio of total debt to total assets versus the prior year. It is intended to capture debt covenants incentives for earnings manipulation.

\section{TATA: Total Accruals to Total Assets}

This assesses the extent to which managers make discretionary accounting choices to alter earnings. Total accruals are calculated as the change in working capital accounts other than cash less depreciation. It measures a risk relating to accrual policies being used as a financing mechanism for losses.

\subsection{Sample and data analysis}

The financial statements of the manufacturing sector listed companies were analysed for the seven-year period from 2013 to 2019. As per Association of Certified Fraud Examiners (2018), the manufacturing sector is the third highest industry victimized by employee fraud, the first being the banking sector and second highest is the public sector entities.

Details extracted from the financial statements of seven consecutive periods of manufacturing
International Journal of Accounting \& Business Finance Vol.6.No.2 December 2020 Issue. pp. 71 - 81

companies were to use to calculate the Beneish M-score model total score. Cut-off scores greater than -2.22 were applied to gauge potential earnings manipulation practice and financial statement frauds of companies. Furthermore, each of the eight variables indices of the Beneish M-Score was scrutinized against the defined manipulation threshold as provided by Beneish (1999).

Descriptive statistics, paired sample t-test to analyze the data, and the results and the discussion is presented in the next section.

\section{Data analysis \\ 4.1 Beneish M Score}

As explained in the preceding section, the Beneish M-score was calculated for seven consecutive years using the financial statements of listed companies in the manufacturing sector in order to identify the possible manipulations in the financial statements. Cut-off scores greater than -2.22 were applied to detect potential earnings manipulation practices and financial statement fraud in the companies. Accordingly, results of the Beniesh M score calculation indicates that in each year of the study, there were companies with a score of greater than -2.22 , which could indicate possible manipulation or frauds in their financial statements.

\subsection{Results of the Beneish M Score for the listed companies in manufacturing sector of CSE (2013-2019)}

As shown in Table 1 below, seven listed companies of manufacturing sector in 2013, eleven listed companies of manufacturing sector in 2014, four listed companies of manufacturing sector in 2015, eight listed companies of manufacturing sector in 2016, seven listed companies of manufacturing sector in 2017, six listed companies of manufacturing sector in 2018 and six listed companies of manufacturing sector in 2019 are detected as likely to be fraudulent financial statements as per Benish M Score Model for the period of 2013-2019. 
Table 1. Results of the Beneish M Score for the listed companies in manufacturing sector of CSE (2013-2019)

\begin{tabular}{|c|c|c|c|c|c|}
\hline Year & 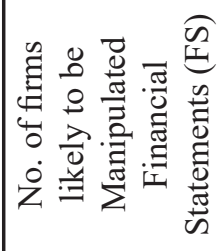 & 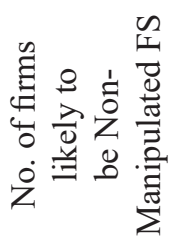 & 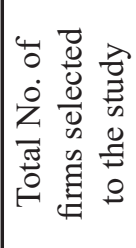 & 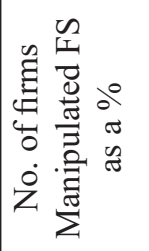 & 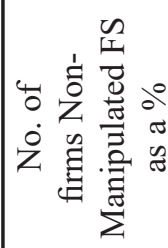 \\
\hline 2013 & 7 & 26 & 33 & $21 \%$ & $79 \%$ \\
\hline 2014 & 11 & 24 & 35 & $31 \%$ & $69 \%$ \\
\hline 2015 & 4 & 31 & 35 & $11 \%$ & $89 \%$ \\
\hline 2016 & 8 & 26 & 34 & $24 \%$ & $76 \%$ \\
\hline 2017 & 7 & 28 & 35 & $20 \%$ & $80 \%$ \\
\hline 2018 & 6 & 27 & 33 & $18 \%$ & $82 \%$ \\
\hline 2019 & 6 & 25 & 31 & $19 \%$ & $81 \%$ \\
\hline
\end{tabular}

\subsection{Paired sample t-test}

Since the current current study examines whether the eight ratios used in the Beniesh model are significantly different between manupulated and non-manipulated firms, the above Beniesh $\mathrm{M}$ score calculations were extended to enable a paired sample $t$-test in order to compare the equality of the subsamples of manipulated and non-manipulated firms.

Tables 2 and 3 give the paired sample statistics and results of the $t$-test respectively. According to $t$-values and their statistical significance shown in the Table 3, comparisons of manipulated DSRI and non-manipulated DSRI, manipulated GMI and non-manipulated GMI, manipulated SGI and non-manipulated SGI manipulated LVGI and non-manipulated LVGI, as well manipulated TATA and nonmanipulated TATA reveal statistically significant differences in terms of their mean values. Therefore, it can be concluded that DSRI, GMI, SGI, LVGI and TATA ratios used in the Beniesh model are shown statistically significant difference between manipulated and non-manipulated firms of manufacturing sector in Sri Lanka.

Table 2. Paired samples statistics

\begin{tabular}{|l|l|r|r|r|r|}
\hline \multicolumn{2}{|c|}{} & \multicolumn{1}{c|}{ Mean } & \multicolumn{1}{c|}{ N } & \multicolumn{1}{c|}{$\begin{array}{c}\text { Std. } \\
\text { Deviation }\end{array}$} & \multicolumn{1}{c|}{$\begin{array}{c}\text { Std. Error } \\
\text { Mean }\end{array}$} \\
\hline \multirow{2}{*}{ Pair 1 } & DSRIM & 2.5917 & 49 & 6.08030 & .86861 \\
\cline { 2 - 6 } & DSRINM & .8207 & 49 & .38558 & .05508 \\
\hline \multirow{2}{*}{ Pair 2 } & GMIM & 1.2706 & 49 & 1.12573 & .16082 \\
\cline { 2 - 6 } & GMINM & .7926 & 49 & .70039 & .10006 \\
\hline \multirow{2}{*}{ Pair 3 } & AQIM & 14.8818 & 49 & 96.28646 & 13.75521 \\
\cline { 2 - 6 } & AQINM & 1.1316 & 49 & .50706 & .07244 \\
\hline \multirow{2}{*}{ Pair 4 } & SGIM & 1.7718 & 49 & 2.55825 & .36546 \\
\cline { 2 - 6 } & SGINM & 1.0165 & 49 & .25610 & .03659 \\
\hline
\end{tabular}




\begin{tabular}{|l|l|r|r|r|r|}
\hline \multirow{2}{*}{ Pair 5 } & DEPIM & 1.0829 & 49 & .72552 & .10365 \\
\cline { 2 - 6 } & DEPINM & 1.1001 & 49 & .50233 & .07176 \\
\hline \multirow{2}{*}{ Pair 6 } & SGAIM & 1.0561 & 49 & .29813 & .04259 \\
\cline { 2 - 6 } & SGAINM & 6.3565 & 49 & 36.88265 & 5.26895 \\
\hline \multirow{2}{*}{ Pair 7 } & LVGIM & .8966 & 49 & .32763 & .04680 \\
\cline { 2 - 6 } & LVGINM & 1.0528 & 49 & .44973 & .06425 \\
\hline \multirow{2}{*}{ Pair 8 } & TATAM & .1055 & 49 & .14570 & .02081 \\
\cline { 2 - 6 } & TATANM & -.0603 & 49 & .13273 & .01896 \\
\hline
\end{tabular}

Table 3. Results of the paired sample test

\begin{tabular}{|c|c|c|c|c|c|c|c|c|c|}
\hline \multirow{3}{*}{\multicolumn{2}{|c|}{ Mean Diff. }} & \multicolumn{5}{|c|}{ Paired Differences } & \multirow[t]{3}{*}{$\mathbf{t}$} & \multirow[t]{3}{*}{ df } & \multirow{3}{*}{$\begin{array}{l}\text { Sig. } \\
(2- \\
\text { tailed) }\end{array}$} \\
\hline & & \multirow{3}{*}{$\begin{array}{c}\begin{array}{c}\text { Std. } \\
\text { Deviation }\end{array} \\
1.77106\end{array}$} & \multirow{3}{*}{$\begin{array}{l}\text { Std. } \\
\text { Error } \\
\text { Mean }\end{array}$} & \multicolumn{2}{|c|}{$\begin{array}{l}95 \% \text { Confidence } \\
\text { Interval of the } \\
\text { Difference }\end{array}$} & & & & \\
\hline & & & & Lower & Upper & & & & \\
\hline Pair 1 & $\begin{array}{l}\text { DSRIM - } \\
\text { DSRINM }\end{array}$ & & & .8570 & .04779 & 3.49433 & 2.066 & 48 & .044 \\
\hline Pair 2 & $\begin{array}{l}\text { GMIM - } \\
\text { GMINM }\end{array}$ & .47801 & 1.64205 & .2345 & .00636 & .94966 & 2.038 & 48 & .047 \\
\hline Pair 3 & $\begin{array}{l}\text { AQIM - } \\
\text { AQINM }\end{array}$ & 13.75017 & 96.34640 & 13.763 & -13.9237 & 41.42409 & .999 & 48 & .323 \\
\hline Pair 4 & $\begin{array}{l}\text { SGIM - } \\
\text { SGINM }\end{array}$ & .75532 & 2.57595 & .36799 & .01542 & 1.49522 & 2.053 & 48 & .046 \\
\hline Pair 5 & $\begin{array}{l}\text { DEPIM - } \\
\text { DEPINM }\end{array}$ & -.01714 & .87103 & .12443 & -.26733 & .23305 & -.138 & 48 & .891 \\
\hline Pair 6 & $\begin{array}{l}\text { SGAIM - } \\
\text { SGAINM }\end{array}$ & -5.30039 & 36.89225 & 5.2703 & -15.8970 & 5.29630 & -1.006 & 48 & .320 \\
\hline Pair 7 & $\begin{array}{l}\text { LVGIM - } \\
\text { LVGINM }\end{array}$ & -.15623 & .50942 & .07277 & -.30255 & -.00991 & -2.147 & 48 & .037 \\
\hline Pair 8 & $\begin{array}{l}\text { TATAM - } \\
\text { TATANM }\end{array}$ & .16577 & .20585 & .02941 & .10664 & .22490 & 5.637 & 48 & .000 \\
\hline
\end{tabular}




\section{Conclusion}

Financial statement frauds and manipulations have become a common problem in today's business context causing dire consequences for business as well as the economy. Detecting financial statement fraud is not an easy task and requires a thorough knowledge of the nature of the fraud, why it is committed and concealed. Given this complexity, the current study tried to investigate the applicability of the Beniesh M Score model to capture either the financial statement distortions that can result from manipulation or preconditions that might prompt companies to engage in such activity. This model employs eight ratios calculated with financial statement figures to capture either financial statement distortions resulting from earnings manipulation or to identify the inclination to engage in earnings manipulation. For the current study, listed companies of manufacturing sector of the Colombo Stock Exchange were used over seven consective years 2013 to 2019 . The results suggest that in each year of the study, there are companies with a Beneish M Score of greater than -2.22, which could indicate possible manipulations of their financial statements. Further, the analysis was extended to include a paired sample $t$-test in order to investigate whether there were significant differences in the ratios between manipilated and non-manupulated firms indicated by the Beniesh M Score. Results of the $t$-test show that five ratios, DSRI,GMI,SGI LVGI and TATA out of eight used in the Beniesh model are statistically showed significant differences as between manipulated and non-manipulated firms. With these results, it can be concluded that the Benish M Score model could be used as a risk assessment tool to identify possible manipulations and frauds in the financial statemets.

Thus it is concluded that top level management, auditors, forensicaccountants, accountants, regulatory authorities and other stakeholders can use the Benish M Score model to detect the red flags of financial ststement frauds in Sri Lankan context.

Findings of this study need to be interpreted in light of its limitations, although most of these are common to this type of study. The period for analysis is short it would be of interest to
International Journal of Accounting \& Business Finance Vol.6.No.2 December 2020 Issue. pp. 71 - 81

extend the time horizon. Furhter, the sample of companies selected are limited and care needs to be taken when generalizing results to other countries and cross-contextual comparison is also not facilitated through this study

\section{References}

Anh N.H., Linh N.H., (2016), Using the M- score Model in Detecting Earnings Management: Evidence from NonFinancial Vietnamese Listed Companies, VNU Journal of Science: Economics and Business, Vol. 32, No. 2, 14-23.

Association of Certified Fraud Examiners, (2016), Report to Nations, United State of America.

Association of Certified Fraud Examiners, (2018), Report to Nations, United State of America.

Association of Certified Fraud Examiners, (2020), Report to Nations, United State of America.

Association of Certified Fraud Examiners. (2016), Fraud Examiners Manual, United State of America.

Beneish, Messod D., (1999), The Detection of Earnings Manipulation, Financial Analysts Journal, September/October, pp. 24-36.

Cressey, D.R. (1953).Other Peoples' Money, Montclair, Glencoe: Free Press.

Cressey, D.R. (1973).Other Peoples' Money: A study in the social psychology of embezzlement. Glencoe: Free Press.

Dalnial H., Kamaluddin A., Sanusi Z.M., Khairuddin K.S., (2014), Detecting Fraudulent Financial Reporting through Financial Statement Analysis, Journal of Advanced Management Science Vol. 2, 
No. 1, March 2014.

EY, (2015), Fraud Survey 2015. Sri Lanka: EY Forensic.

Gupta, P.K.G.S., (2015), Corporate frauds in India - Perceptions and emerging issues, Journal of Financial Crime, Vol. 22 Iss 1 pp. 79-103.

Kamal M.F.S., Salleh M.F.M., (2016), Detecting Financial Statement Fraud by Malaysian Public Listed Companies: The Reliability of the Beneish M-Score Model, Journal of Auditing 46(2016) 23 - 32.

Kassem, R., Higson, A. (2012). The New Fraud Triangle Model, Journal of Emerging Trends in Economics and Management Sciences (JETEMS), Vol. 3, No. 3, pp.191-195.

KPMG, (2012), Fraud Survey 2012. Sri Lanka: KPMG Forensic.
International Journal of Accounting \& Business Finance

Vol.6.No.2 December 2020 Issue. pp. 71 - 81

in Greece, Journal of Financial Crime, Vol. 23 Issue: 4, pp.1063-1073.

Talab H.R., Flayyih H.,H., Ali S.,I., (2017), International Journal of Applied Business and Economic Research, Serials Publications Pvt. Ltd.

Tarjo \& Herawati N., (2015), Application of Beneish M-Score Models and Data Mining to Detect Financial Fraud, 2nd Global Conference on Business and Social Science-2015, GCBSS-2015, 17-18 September 2015, Bali, Indonesi.

Wolfe, D.T. \& Hermonson D.R. (2004), The Fraud Diamond: Considering the Four Elements of Frauds, The CPA Journal, ProQuest Central. 